\title{
ANALISIS EKOLOGIS VEGETASI POHON DI DAERAH TANGKAPAN AIR (DTA) MATA AIR GEGER KABUPATEN BANTUL YOGYAKARTA
}

\author{
Remigius Binsasi ${ }^{1}$, Retno Peni Sancayaningsih ${ }^{2}$, Sigit Heru Murti ${ }^{3}$ \\ ${ }^{1}$ Universitas Timor, binsasiremigius@gmail.com \\ ${ }^{2}$ Fakultas Biologi, Universitas Gadjah Mada, retpeni@ugm.ac.id \\ ${ }^{3}$ Fakultas Geografi, Universitas Gadjah Mada, sigit@geo.ugm.ac.id
}

\begin{abstract}
Potential water resources in Indonesia is very abundant, but the availability of water varies greatly based on the dimensions of space and time. Climate change, ecosystem degradation and land use change in Watershed resulted in a crisis of water in the dry season. The study aims to analyze the species composition and structure of vegetation and role or function in conserving water. Analysis of vegetation ecologically ie vegetation type, density, frequency, Total Basal area, INP, and the Diversity Index. This study was conducted in November 2015 - April 2016 in the watershed springs Geger. The sampling method is the method of least squares plot randomly. Watershed determination is based Citra Quikbird for vegetation class divisions. In addition, measurement of soil moisture content, physico chemical. The results showed that the area watershed spring Geger overall popularity vegetation classes is 9875.26 ha. Number of individual species found most of each class of vegetation in a row that Swietania mahogany, ( L. ) Jacq; Tectona grandis, L. Acacia auriculiformis A. Cunn Ex Benth; Tectona grandis, L. and Gnetum gnemon, L. Importance Value Index is the highest of each class of vegetation that is Swietania mahogany, ( L. ) Jacq ( $110.84 \%$ ) for class I; Tectona grandis, L. for class II, III, IV respectively, namely ( $85.71 \%$ ) ( $72.52 \%$ ) ( $115.19 \%$ ) ; and Gnetum gnemon , L. ( $182.21 \%$ ) for class V. The results of analysis of species diversity index ( Shannon winner) showed that the diversity of species is strongly correlated with the number of species in a region watershed, while the value of equity index or Evenness showing distribution species in each class DTA vegetation springs Geger consecutive namely $(1.1 ; 1.5 ; 1.3 ; 1.4$; and 1.2 ) with a high category.
\end{abstract}

Keywords : Ecologys Analysis, Tree Vegetation, WCA, Geger

ISSN Print $\quad: 1979-7141$ 


\section{Pendahuluan}

Air merupakan komponen penting bagi proses kehidupan. Salah satu sumber air tanah yang potensial adalah mata air. Sumber air ini memberikan dukungan terhadap pertumbuhan dan perkembangan peradaban di bumi. Keberadaan sumber daya air tersebut perlu dijaga dan dilestarikan, baik dalam pemanfaatan maupun pengelolaannya. Ketersediaan air sangat bervariasi berdasarkan dimensi ruang dan waktu. Adanya perubahan iklim, kerusakan ekosistem dan perubahan penggunaan lahan di DTA mengakibatkan terjadinya krisis air di musim kemarau.

Vegetasi di DTA memiliki pengaruh besar terhadap ketersediaan air dan nutrien yang ada di dalamnya. Sancayaningsih (2015) mengatakan bahwa pada tahun 2006 di wilayah Geger ketersediaan air sangat melimpah. Segala kebutuhan dapat terpenuhi dengan baik termasuk pengairan untuk lahan pertanian. Beberapa tahun terakhir ini masyarakat Dusun Geger sering terjadi kekurangan air bersih di musim kemarau, sehingga masyarakat harus mendapat pasokan dari PDAM dan BPBD untuk bisa menghidupi kebutuhan harian mereka. Konservasi vegetasi di DTA mata air sangatlah diperlukan untuk menjamin keberlanjutan pendayagunaan mata air serta mencegah dan menanggulangi dampak negatif explorasi air (Arsyad \& Rustiadi, 2012).

Salah satu upaya konservasi air adalah analisis vegetasi pohon pada ekosistem di DTA mata air. Penelitian ini diharapkan dapat diketahui berapa jenis vegetasi pohon pada masingmasing kelas vegetasi. Selain itu, untuk menentukan wilayah DTA mata air Geger Kabupaten Bantul; Menganalisis luas penutupan vegetasi pohon berdasarkan penentuan DTA mata air Geger; Menganalisis komposisi dan struktur vegetasi pohon di DTA mata air Geger.

\section{Kajian Teori}

\subsection{Vegetasi}

Vegetasi adalah sekelompok tumbuhan atau komunitas tumbuhan yang hidup bersamasama dalam suatu ekosistem dan saling berinteraksi satu dengan yang lainnya sehingga mampu memodifikasi habitatnya, mampu memperkaya tanah di sekitarnya, dan dapat mengurangi pancaran sinar matahari (Weaver dan Clements, 1980). Bentuk vegetasi merupakan hasil interaksi faktor-faktor lingkungan seperti tanah, iklim, topografi, kelembaban, $\mathrm{pH}$, suhu, dan intensitas cahaya. Peran vegetasi pada DTA sangat ditentukan oleh jenis dan kerapatannya, karena kerapatan formasi vegetasi dapat mempengaruhi air di dalam tanah (Asdak, 2002).

Indarto (2010) mengatakan bahwa air merupakan substansi yang paling melimpah di permukaan bumi dan komponen utama bagi semua makluk hidup serta merupakan kekuatan utama secara konstan yang dapat membentuk permukaan bumi. Air juga merupakan faktor penentu dalam pengaturan iklim di permukaan bumi untuk kebutuhan hidup manusia. John (2013) menambahkan bahwa air merupakan salah satu komponen penting kebutuhan makluk hidup yang harus diatur penggunaannya secara seimbang. Hilangnya fungsi pengatur tata air tersebut ditunjukkan dengan terjadinya banjir pada musim penghujan dan kekeringan pada musim kemarau. Penurunan debit mata air tersebut disebabkan oleh berkurangnya kawasan lindung atau daerah resapan air akibat penebangan hutan secara illegal dan alih fungsi lahan yang mengakibatkan terjadinya lahan kritis dan menurunnya kualitas daerah resapan air (Dinas Kehutanan Provinsi NTB, 2009).

\subsection{Daerah Tangkapan Air}

DTA didefinisikan oleh Wagener et al (2007) sebagai area yang menangkap dan menyimpan air melalui suatu titik dan mengalirkannya melalui suatu saluran dan tergantung pada topografi permukaannya. Ketersediaan mata air sangat tergantung pada kondisi wilayah ekosistem yang merupakan daerah tangkapan air (catchment area). Kemiringan lereng dan luas DTA berdampak pada besarnya debit air dan vegetasi yang hadir dalam wilayah DTA (Dodds, 2002). DTA juga merupakan suatu ekosistem dengan unsur utamanya terdiri atas sumber daya alam (tanah, air, dan vegetasi) dan sumber daya manusia sebagai pemanfaat sumber daya alam 
(Setia, 2008). Salah satu bagian dari DTA adalah Vegetasi. Vegetasi memiliki potensi untuk dijadikan sebagai salah satu alternatif strategi konservasi air dan tanah. Peran vegetasi dalam upaya mendukung konservasi air dan tanah diantaranya, kemampuan vegetasi dalam menahan air, mengurangi limpasan dan mengurangi kapasitas mengalirnya air di permukaan, mengurangi laju erosi serta mencegah terjadinya sedimentasi. Peranan ini sangat ditentukan oleh struktur dan komposisi tumbuhan penyusun komunitas tumbuhan di daerah tersebut.

Kebutuhan air bagi vegetasi berbeda-beda, tergantung jenis tumbuhan dan fase pertumbuhannya. Pada musim kemarau, tumbuhan sering mendapatkan cekaman air (water stress) karena kekurangan pasokan air di daerah perakaran dan laju evapotranspirasi yang melebihi laju absorbsi air oleh tumbuhan (Levit, 1980) Sebaliknya pada musim penghujan, tumbuhan sering mengalami kondisi jenuh air. Air seringkali membatasi pertumbuhan dan perkembangan tanaman. Respon tumbuhan terhadap kekurangan air dapat dilihat pada aktivitas metabolismenya, morfologinya, tingkat pertumbuhannya, atau produktivitasnya.

\section{Metode Penelitian}

\subsection{Waktu dan Lokasi Penelitian}

Penelitian ini telah dilaksanakan di Dusun Geger Desa Seloharjo Kecamatan Pundong Kabupaten Bantul yang berada pada wilayah dengan ketinggian $200 \mathrm{~m}$ dari atas permukaan laut. Pelaksanaan penelitian telah dilaksanakan dari bulan November 2015 - April 2016. Lokasi penelitian menggunakan DTA Mata Air Geger Kabupaten Bantul, Yogyakarta. Bahan yang yang digunakan dalam penelitian ini adalah vegetasi pohon dan air.

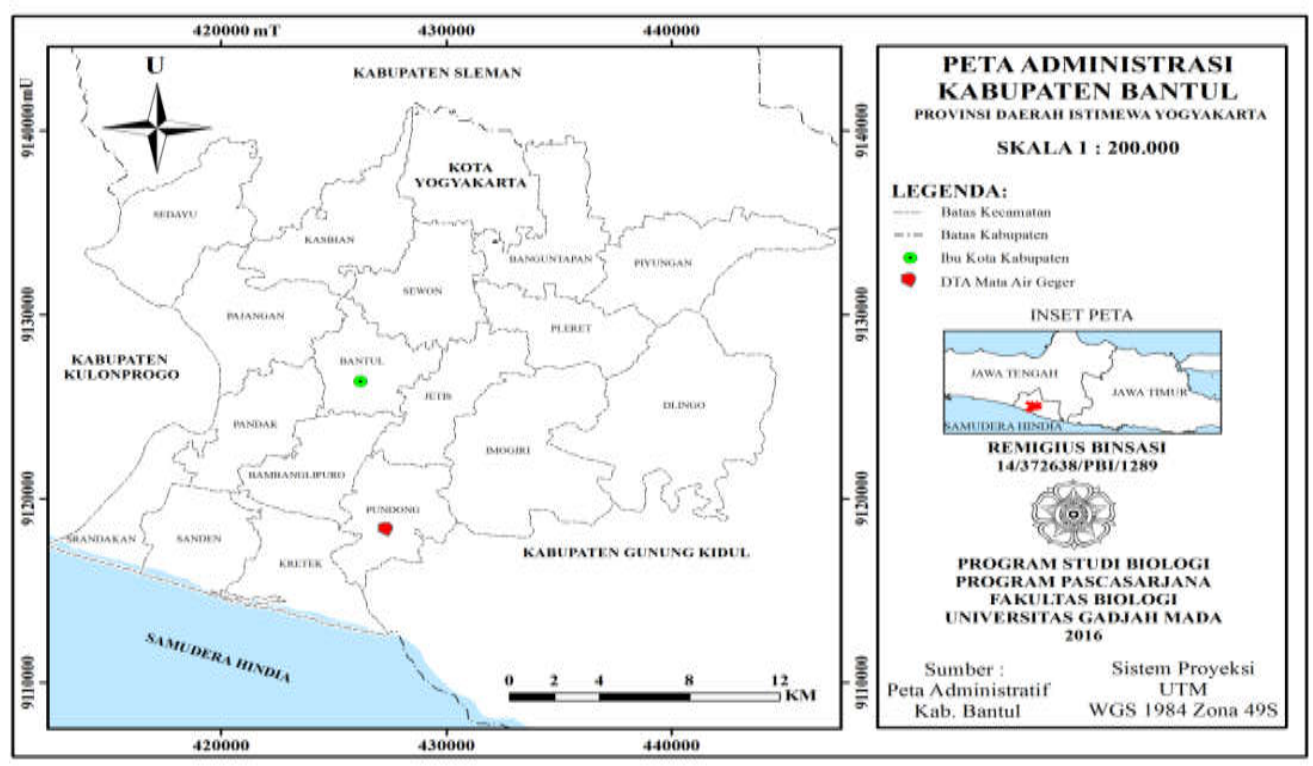

Gambar 1. Peta Administrasi Kabupaten Bantul.

\subsection{Prosedur Kerja}

a. Pra Penelitian (Survei)

Melakukan studi pustaka dan penelitian terdahulu yang dapat mendukung penelitian. Selanjutnya dilakukan survei lapangan untuk mengetahui keadaan DTA mata air, ketinggian, kemiringan (slope), jenis tanah, serta informasi mengenai mata air dengan melakukan wawancara terhadap penduduk setempat.

b. Penentuan Unit Sampling dan Luas Daerah Tangkapan Air

Penentuan unit sampling dan deliniasi DTA dilakukan dengan bantuan peta RBI, peta hidrogeologi dan citra satelit Quickbird dengan menggunakan software ArcMap 10.1 untuk mengetahui seberapa luasan vegetasi di DTA dan area mana yang akan di cuplik. 


\section{c. Analisis Struktur Vegetasi Pohon}

Pengambilan data vegetasi pohon menggunakan metode kuadrat/plot berukuran $10 \mathrm{~m} \mathrm{x}$ $10 \mathrm{~m}=100 \mathrm{~m} 2$ secara acak (proporsional random sampling) berdasarkan kelas vegetasi. Jumlah plot yaitu 45 plot. Selain itu, dilakukan pengukuran faktor fisiko kimia pada setiap plot pengamatan masing-masing kelas vegetasi. Data vegetasi dianalisis untuk melihat densitas, frekuensi, luas basal area, dan nilai penting.

Densitas mutlak

$$
\mathrm{DM}=\frac{\text { Jumlahindividu }}{\text { Luas seluruh potak contob. }}
$$

Densitas relatif

$$
\mathrm{DR}=\frac{\text { Dengitas spexise }}{\text { Jumlah dengitas seluruh gpegies }} \times 100 \%
$$

Frekuansi

$$
F=\frac{\text { Jumlah titk agmpling dengan ap A hadix }}{\text { Jumlah seluruh petak contoh }}
$$

Frekuensi relatif

$$
\mathrm{FR}=\frac{\text { frekuengi gpegiesA }}{\text { Jumlah frekuengi geluruh gpegi es }} \times 100 \%
$$

Luas basal area

$$
\text { Lba }=1 / 4 \times \pi \times \text { diameter }{ }^{2} \text {. }
$$

Luas basal area

$$
\text { LbaR }=\frac{\text { luab bagal area gpegi esA }}{\text { totallba seluruh zpesi ses }} \times 100 \% \text {.. }
$$

Nilai penting

$$
\mathrm{NP}=\mathrm{DR}+\mathrm{FR}+\mathrm{LBAR}
$$

\section{d. Analisis Indeks Keanekaragaman}

Keanekaragaman merupakan parameter vegetasi yang sangat berguna untuk membandingkan komunitas pada periode waktu yang berbeda (Fachrul, 2007). Keanekaragaman jenis setiap kelas dan total vegetasi dapat digambarkan dengan Indeks Shannon-Wienner (Barbour, 1987) sebagai berikut:

$$
\mathrm{H}^{\prime}=-\Sigma \frac{\mathbf{m i}}{\mathbf{N}} \log \frac{\mathbf{n j}}{\mathbf{N}} \text {. }
$$

Keterangan :

H' = Indeks keanekaragaman Shannon Wienner

$\mathrm{ni}=$ Jumlah individu dari suatu Jenis $\mathrm{i}$

$\mathrm{N}=$ Jumlah total individu seluruh jenis

Fachrul (2007) mengatakan bahwa Indeks Keanekaragaman jenis Shannon- Wienner didefenisikan sebagai berikut : 1) nilai $\mathrm{H}^{\prime}>3$ menunjukkan bahwa keanekaragamannya tinggi; 2) nilai $H^{\prime}, 1 \leq H^{\prime} \leq 3$ menunjukkan bahwa keanekaragamannya sedang; dan 3) nilai $H^{\prime}<1$ menunjukkan bahwa keanekaragamannya rendah.

Adapun Indeks evenness digunakan untuk menunjukkan kestabilan suatu komunitas tumbuhan dalam setiap kelas vegetasi. Barbour et al (1987), rumus untuk menghitung indeks evenness adalah sebagai berikut:

$$
\mathrm{E}=\frac{\mathrm{H}^{\prime}}{\log 2 \mathrm{~s}}
$$

Keterangan :

E : Indeks evenness

H' : Indeks Keanekaragaman Shannon-Winner

$\mathrm{S} \quad$ : Jumlah spesies. 
Kemerataan dapat diketahui dari perhitungan dengan menggunakan rumus indeks evenness (e). Nilai e $<0,3$ menunjukkan kemerataan spesies rendah; dan nilai e $=0,3-0,6$ menunjukkan kemerataan spesies sedang; serta kemerataan spesies tinggi apabila nilai e $>0,6$.

\section{Hasil dan Pembahasan}

\subsection{Daerah Tangkapan Air (DTA)}

DTA merupakan suatu area yang menangkap dan menyimpan air hujan serta mengalirkan atau melepaskannnya melalui suatu saluran dan tergantung pada topografi lahan (Wagener et al., 2007). Salah satu bagian dari DTA adalah Vegetasi. Peran vegetasi dalam upaya mendukung konservasi air dan tanah diantaranya, kemampuan vegetasi dalam menahan air, mengurangi limpasan dan mengurangi kapasitas mengalirnya air di permukaan, mengurangi laju erosi serta mencegah terjadinya sedimentasi. Beberapa faktor penting pada vegetasi yang mempengaruhi kelestarian mata air adalah jenis vegetasi, arsitektur atau morfologi vegetasi, tingkat pertumbuhan dan umur vegetasi, kerapatan dan nilai penting vegetasi, tinggi vegetasi serta vegetasi lantai (Sancayaningsih dkk, 2013).

\subsection{Penentuan DTA}

Penentuan DTA dan luas DTA di lokasi penelitian dengan menginterpretasi visual citra Quikbird dengan pertimbangan berdasarkan slope atau letak kemiringan pada wilayah tersebut. Hasil interpretasi visual citra Quikbird disajikan pada Gambar 2.

\subsection{Interpretasi Kerapatan Vegetasi}

Hasil perhitungan dan persentase masing-masing kelas berdasarkan kerapatan vegetasi dan titik samplingnya disajikan pada Tabel 1 dan Gambar 5

Tabel 1. Luas total DTA mata air Geger Kabupaten Bantul

\begin{tabular}{|c|c|c|}
\hline Kelas Vegetasi & Luas Tiap Kelas & $(1 \%)$ \\
\hline Kelas I & 67.454 .934 & 6.83 \\
\hline Kelas II & 12.7792 .653 & 12.94 \\
\hline Kelas III & 31.5697 .168 & 31.96 \\
\hline Kelas IV & 22.3821 .865 & 22.66 \\
\hline Kelas V & 14.2342 .194 & 14.41 \\
\hline Pemukiman & 11.0417 .550 & 11.18 \\
\hline Jumlah & 9875.26364 & 100 \\
\hline
\end{tabular}

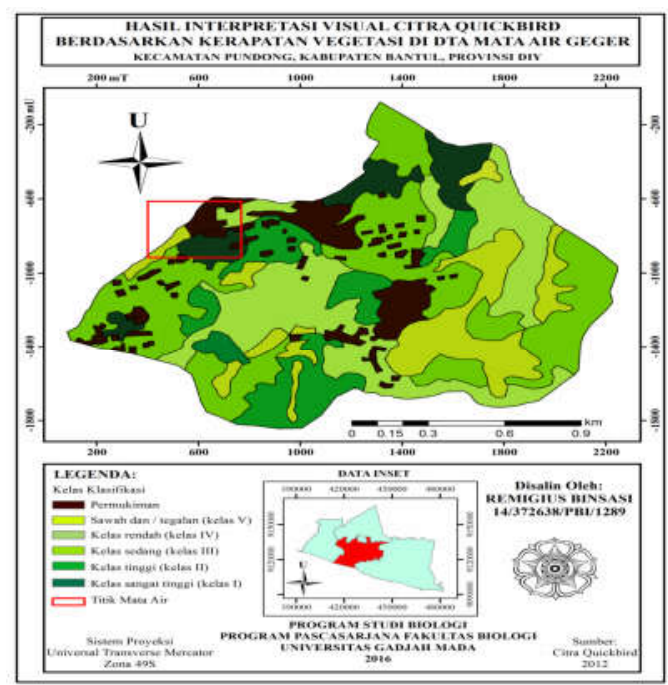

Gambar 2. Hasil Interpretasi Visual Citra Quikbird Berdasarkan Kerapatan Vegetasi di DTA Mata Air Geger Bantul 
Berdasarkan luas total DTA mata air Geger dari masing-masing kelas vegetasi dapat digambarkan dalam bentuk persentase sebagai berikut:

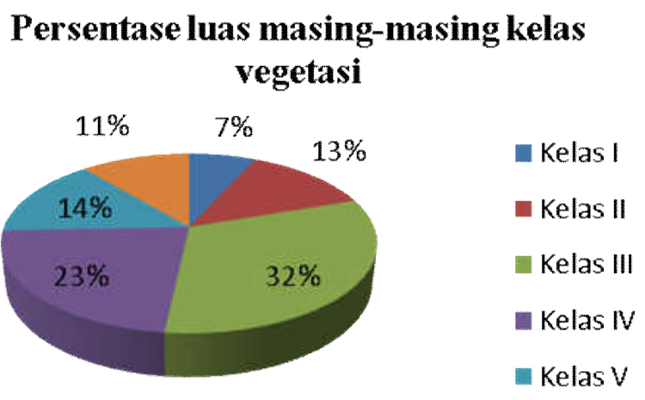

Gambar 3. Persentase luas masing masing vegetasi

\subsection{Stuktur dan Komposisi Vegetasi Pohon}

\section{a. Analisis Vegetasi Pohon di DTA Mata Air Geger}

Analisis vegetasi merupakan suatu cara untuk mempelajari susunan atau komposisi jenis dan bentuk atau struktur vegetasi (Ardhana, 2012). Hasil analisis vegetasi pohon yang diperoleh berupa jumlah individu, jumlah spesies, jumlah famili, dan diameter batang pohon. Data yang diperoleh selanjutnya dilakukan perhitungan densitas relatif (DsR), frekuensi relatif (FR), luas basal area (LBA) relatif, dan indeks nilai penting (INP). Hasil perhitungan INP pada masingmasing kelas vegetasi dapat di lihat Gambar 4-8

1. Hasil Perhitungan INP Kelas I (Kerapatan Sangat Tinggi)

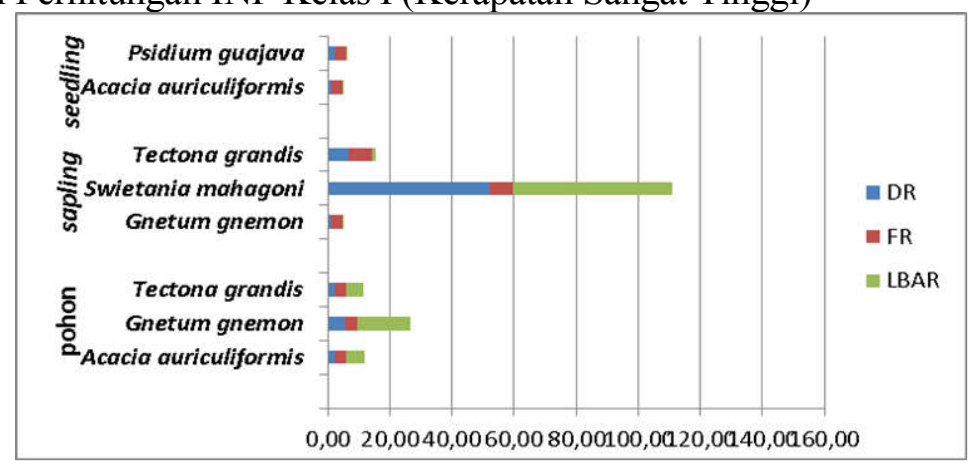

Gambar 4. Nilai INP vegetasi pohon kelas I di DTA mata air Geger

Berdasarkan Gambar 4 diketahui bahwa INP kelas I, didominasi oleh spesies Swietania mahagoni dengan INP (110.8\%) kemudian diikuti oleh Gnetum gnemon dengan INP sebesar $(31.38 \%)$, Acacia auriculiformis dengan INP sebesar (29.9\%) dan spesies Tecotana grandis dengan INP $(27.1 \%)$.

2. Hasil Perhitungan INP Kelas II (Kerapatan Tinggi)

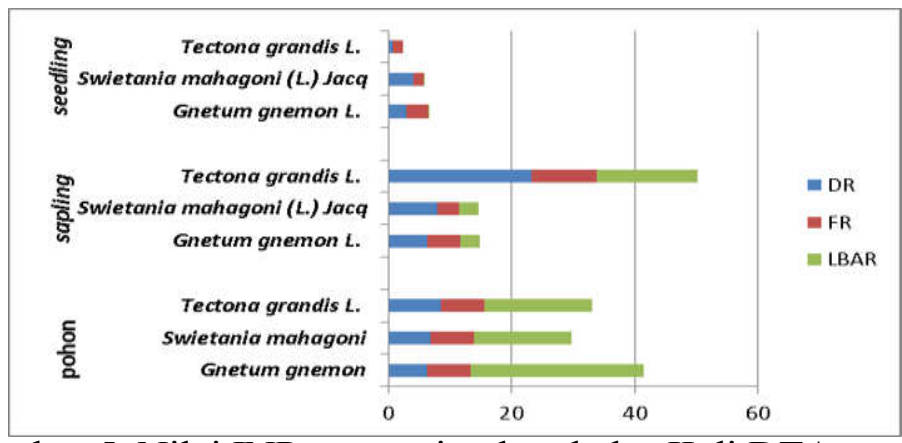

Gambar 5. Nilai INP vegetasi pohon kelas II di DTA mata air Geger 
Berdasarkan Gambar 5 diketahui bahwa spesies yang memiliki INP tertinggi adalah T. grandis dengan nilai pentingnya (85.7\%) dan INP terendah dimiliki oleh spesies A.occidentale dan $\mathrm{H}$. tiliaceus $(2.4 \%)$. Spesies $\mathrm{T}$. grandis merupakan spesies dengan jumlah individu terbanyak. Hal ini menunjukkan bahwa $T$. grandis merupakan spesies pohon penghasil kayu yang memiliki nilai ekonomi yang tinggi sehingga di sekitar wilayah DTA sengaja ditanami jati sebagai lahan produktif.

3. Hasil Perhitungan INP Kelas III (Kerapatan Sedang)

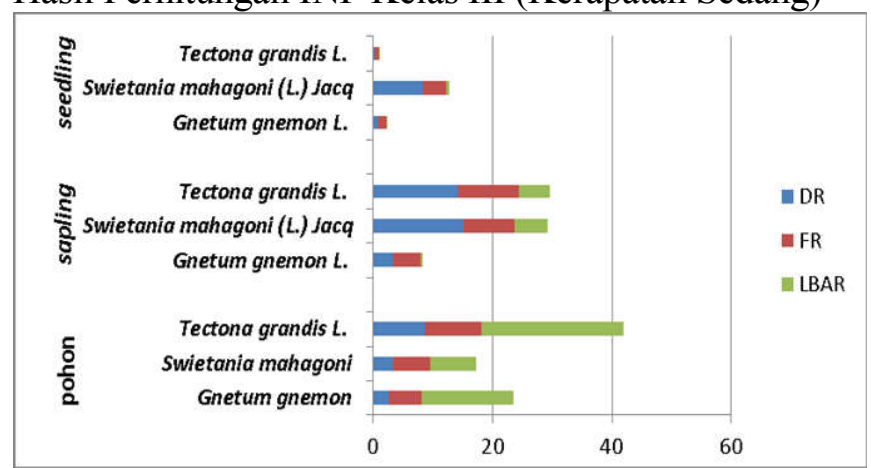

Gambar 6. Nilai INP vegetasi pohon kelas III di DTA mata air Geger

Berdasarkan Gambar 6, spesies yang memiliki INP tertinggi adalah T. grandis yaitu $72.5 \%$ dan INP terendah dimiliki oleh spesies A. occidentale dan $\mathrm{H}$. tiliaceus yaitu $0.9 \%$. Hal ini menunjukan bahwa $\mathrm{T}$. grandis memiliki kemampuan bereproduksi, penyebaran atau distribusi tumbuhan, dan daya adaptasi dalam komunitas tumbuhan. Faktor-faktor lingkungan juga berpengaruh terhadap hadir atau tidaknya suatu spesies dalam kawasan DTA mata air serta keanekaragaman makluk hidup penyusun suatu wilayah.

4. Hasil Perhitungan INP Kelas IV (Kerapatan Rendah)

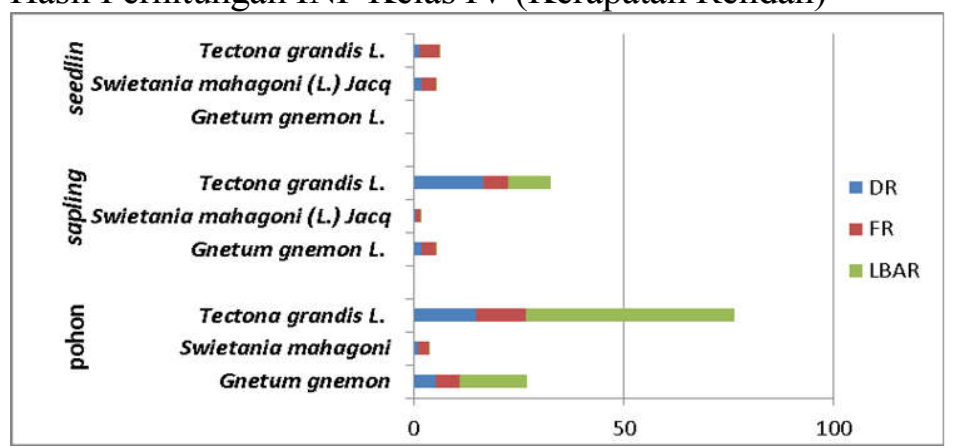

Gambar 7. Nilai INP vegetasi pohon kelas IV di DTA mata air Geger

Berdasarkan Gambar 6 menunjukkan bahwa terdapat perbedaan jumlah INP untuk masing-masing spesies. Spesies yang memiliki INP tertinggi hingga terendah secara berturutturut adalah T. grandis dengan indeks nilai penting adalah $115.2 \%$, T. bellirica $54.2 \%$, G. gnemon $32.2 \%$, A. auriculiformis $32.2 \%$. Selanjutnya diikuti S. mahagoni dengan INP $10.8 \%$, A. scholaris dan A. heterophyllus masing-masing memiliki INP yaitu $8.5 \%$ dan $8.4 \%$; A. muricata 7.2\%, Ficus Sp dan G. sepium dengan masing-masing INP adalah $6.6 \%$ dan $6.2 \%$, C. nucifera dengan INP 5.9\%; M. indica dengan INP 4.9\%, kemudian spesies A. communis $1.7 \%$, L. leucocephalo $1.6 \%$, P. guajava $1.6 \%$. Perbedaan tersebut dipengaruhi oleh faktor-faktor lingkungan sebagai salah satu faktor pembatas akan hadirnya spesies dalam suatu wilayah DTA mata air. 
5. Hasil Perhitungan INP Kelas V (Sawah dan atau Tegalan)

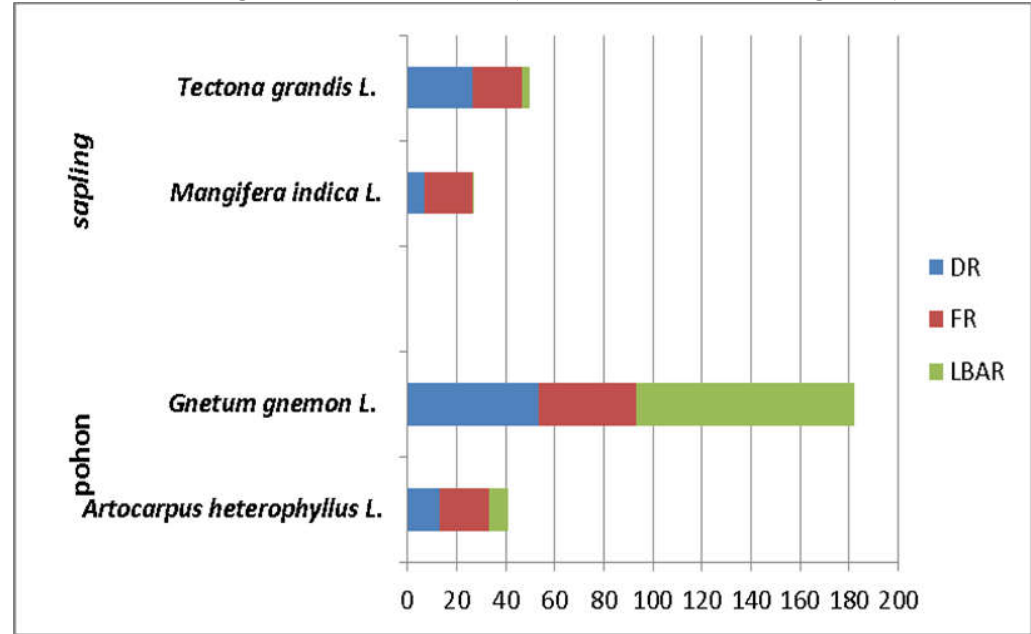

Gambar 8. Nilai INP vegetasi pohon kelas V di DTA mata air Geger

Berdasarkan Gambar 8 diketahui bahwa spesies yang memiliki INP tertinggi hingga terendah secara berturut-turut adalah G.gnemon 182.2\%, T. grandis 50\%), A.heterophyllus 41\%, dan M.indica 26.9\%. Perbedaan tersebut dipengaruhi oleh faktor-faktor lingkungan sebagai salah satu faktor pembatas akan hadirnya spesies dalam suatu wilayah DTA mata air. Faktor lingkungan yang dimaksud diantaranya suhu, $\mathrm{pH}$, dan ketersediaan nutrient dalam tanah.

\section{b. Keanekaragaman dan Kestabilan/Kemerataan}

1. Keanekaragaman

Keanekaragaman spesies digunakan untuk menyatakan struktur komunitas dan mengukur stabilitas komunitas (Indriyanto, 2012). Keanekaragaman vegetasi dipengaruhi oleh beberapa hal yaitu ketersediaan makanan di habitat dan struktur vegetasi penyusun habitat, kompetisi antar spesies, kemampuan adaptasi tumbuhan dan berbagai faktor lingkungan lainnya. Hasil perhitungan indeks keanekaragaman jenis menurut Shannon Winner dapat di lihat pada Gambar 9.

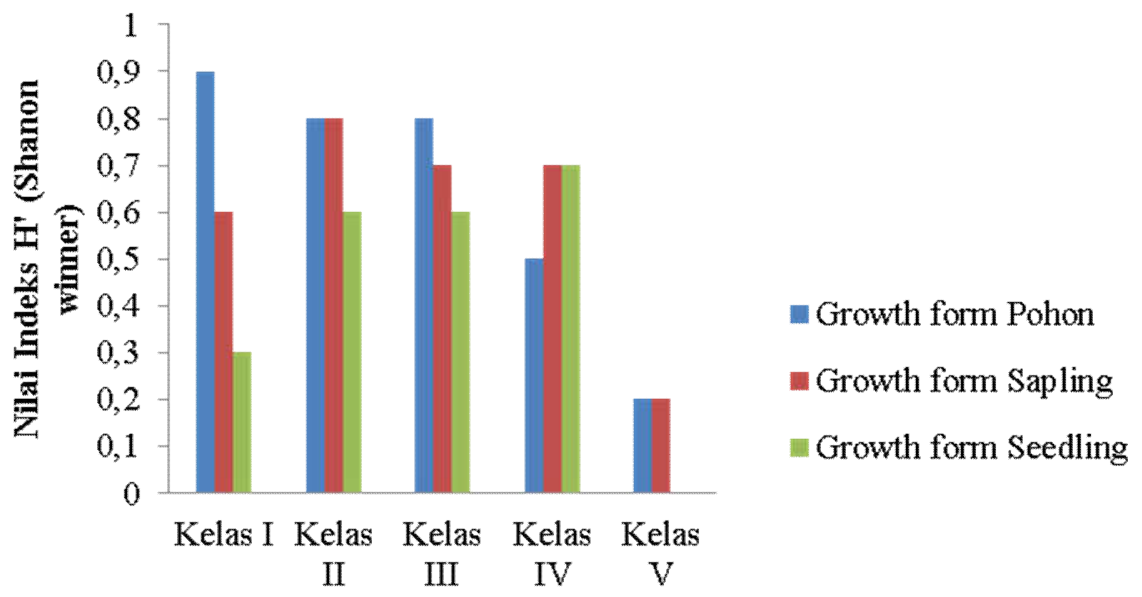

Gambar 9. Indeks keanekaragaman spesies pada masing-masing kelas vegetasi di DTA mata air Geger

Berdasarkan Gambar 9 diketahui bahwa keanekaragaman spesies di DTA mata air Geger pada masing-masing kelas vegetasi adalah berbeda, dengan nilai H' tergolong sedang untuk kelas I (1.8); kelas II (2.3); kelas III (2.2); dan kelas IV (2.1); sedangkan untuk kelas $\mathrm{V}$ tergolong rendah dengan nilai indeks keanekaragaman $\left(\mathrm{H}^{\prime}\right)$ adalah (0.4). 
Hal ini didukung dengan penelitian Ogbemudia, et al. (2010) yang menyatakan bahwa keanekaragaman vegetasi merupakan hasil interaksi antara adaptasi dan konflik spesies. Rendahnya keanekaragaman spesies untuk kelas V dikarenakan pada DTA mata air hanya ditemukan sedikit jumlah jenis/spesies.

\section{Kestabilan/Kemerataan}

Kestabilan/kemerataan (Evennes) digunakan untuk menunjukkan kestabilan suatu komunitas tumbuhan. Hasil analisis indeks evenness (e) yang diperoleh dapat ditunjukkan pada Gambar 10.

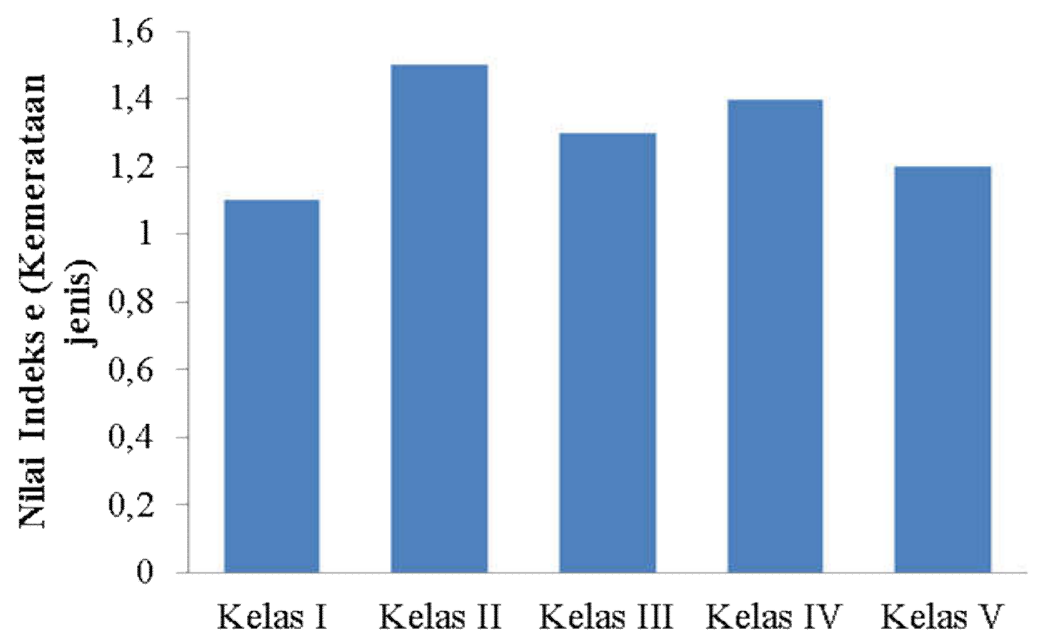

Gambar 10. Indeks kestabilan/ kemerataan spesies (evennes) pada masing-masing kelas vegetasi di DTA mata air Geger

Berdasarkan Gambar 10 juga diketahui bahwa indeks kestabilan/ kemerataan spesies (evennes) kelas I sampai kelas V di DTA mata air Geger tergolong tinggi yaitu kelas I dengan nilai $\mathrm{e}=1.1$; kelas II dengan nilai $\mathrm{e}=1.5$; kelas III dengan nilai $\mathrm{e}=1.3$; kelas IV dengan nilai $\mathrm{e}=1.4$ dan kelas $\mathrm{V}$ dengan nilai $\mathrm{e}=1.2$. Tingginya kemerataan spesies (evennes) dapat menunjukkan distribusi spesies di masing-masing kelas vegetasi DTA mata air Geger tinggi.

\section{Penutup}

\section{a. Kesimpulan}

Berdasarkan permasalahan dan hasil penelitian dapat disimpulkan sebagai berikut: Jumlah individu spesies terbanyak yang ditemukan di masing-masing kelas vegetasi di DTA mata air Geger secara berturut-turut: kelas I, Swietania mahagoni L. Jacq; kelas II, Tectona grandis L.; kelas III, Acacia auriculiformis A.cunn. ex Benth; kelas IV, Tectona grandis L.; kelas V, Gnetum gnemon L. INP tertinggi di masing-masing kelas vegetasi di DTA mata air Geger secara berturut-turut: Swietania mahagoni L.Jacq (110.9\%); Tectona grandis L. (85.7\%; $72.6 \% ; 115.2 \%)$ Gnetum gnemon L. (182.231\%).

\section{b. Saran}

Bagi peneliti sejenis yang ingin melanjutkan dan mengembangkan penelitian ini diharapkan dilakukan di dua musim yang bebeda (kemarau dan hujan) agar dapat diketahui perbedaan vegetasi yang hadir di sekitar DTA. Bagi masyarakat, untuk mengatasi masalah kekurangan air diperlukan upaya dalam menjaga vegetasi yang berada di sekitar wilayah DTA dan bagi pemerintah diharapkan mengambil kebijakan yang tepat dalam konservasi air di DTA. 


\section{DAFTAR PUSTAKA}

Adi, S. 2009. Pemanfaatan dan Konservasi Sumber Air Dalam Keadaan Darurat. JAI. 5 (1): 1-8

Arsyad, S. dan Rustiadi, E. 1983. Penyelamatan Tanah, Air, dan Lingkungan. Yogyakarta: Yayasan Obor Indonesia.

Asdak, C. 2002. Hidrologi dan Pengelolaan Daerah Aliran Sungai. Yogyakarta: UGM Press);( Sulistio, H. 2012. Konservasi Daerah Tangkapan Air Cipta Graha. Jurnal Media SainS, 4(1): 36-42).

Barbour, M. G., Burk, J. G., and. Pitts, W. D. 1987. Terestrial Plant Ecology. $2{ }^{\text {nd }}$ Ed. California : Benjamin/Cummings Publishing Company, Inc.

Chandy, K.T. 2010. Water Conservation. Booklet No 126 Soil and Water Conservation: SWCS5

Davis, S.N and R.J.M De Wiest, 1966. Hydrogeology. John Willey \& Sons. New York.

Daubenmire, R. 1968. Plant Communities: A Text Book of Plant Synecology. New York: Harper \& Row Publishers) \& (Mueller-Dombois and H. Ellenberg, 1974. Aims and Method of Vegetation Ecology. Toronto: John Willey \& Sons Inc..

Dodds, W. K. 2002. Freshwater Ecology: Concepts \& Enviromental Applications. USA: Academic Press, p. 71-74.

Marsono, Dj. 2008. Keharusan Basis Ekosistem Dalam Pengelolaan Hutan dan Lahan. Pidato Dies Natalis Fakultas Kehutanan UGM ke- 45 tanggal 7 November 2008. Yogyakarta.

Sancayaningsih, R. P., Saputra, A. and Fatimatuzzahra. 2014. Tree Vegetation Analysis of Catchment Areas in Various Springs. Proceding. The $4^{\text {th }}$ Annual Basic Science International Conference (BaSIC) in conjunction with The $5^{\text {th }}$ International Conference on Global Conservation (ICGRC)2014. UB, February 12-13 2014.

Wagener, T., M. Sivapalan., P. Troch and R. Woods. 2007. Catchment Classification and Hydrologyc Similarity. Geography Compass. 1(4): 901-931. 